Artvin Çoruh Üniversitesi

Orman Fakültesi Dergisi

ISSN:2146-1880, e-ISSN: 2146-698X

Yıl: 2021, Cilt: 22, Sayı:2, Sayfa:266-277

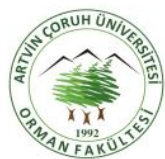

ofd.artvin.edu.t

(c) (i)
Artvin Coruh University

Journal of Forestry Faculty

ISSN:2146-1880, e-ISSN: 2146-698X

Year: 2021, Vol: 22, Issue: 2, Pages:266-277

\title{
Ekolojik sürdürülebilirlik kavramının 3B gölge analizi tekniği ile irdelenmesi: Amasya Üniversitesi Hâkimiyet Yerleşkesi örneği
}

\author{
The Concept of ecological sustainability examined via 3D shadow analysis: the case of Amasya University Hâkimiyet \\ Campus
}

\author{
Sultan Sevinç KURT KONAKOĞLU1(D), Mustafa Taha KESKINER ${ }^{2}$ \\ ${ }^{1}$ Amasya Üniversitesi, Mimarlık Fakültesi, Kentsel Tasarım ve Peyzaj Mimarlığı Bölümü, Amasya, Türkiye \\ ${ }^{2}$ Amasya Üniversitesi, Fen Bilimleri Enstitüsü, Teknoloji ve İnovasyon Yönetimi Anabilim Dalı, Amasya, Türkiye
}

\begin{tabular}{l} 
Eser Bilgisi / Article Info \\
Araştırma makalesi / Research article \\
DOI: 10.17474/artvinofd.912444 \\
\hline Sorumlu yazar / Corresponding author \\
Sultan Sevinç KURT KONAKOĞLU \\
e-mail: sultansevinc.kurt@amasya.edu.tr \\
\hline Geliş tarihi / Received \\
09.04.2021 \\
Düzeltme tarihi / Received in revised form \\
13.09.2021 \\
Kabul Tarihi / Accepted \\
22.09.2021 \\
Elektronik erişim / Online available \\
18.11.2021
\end{tabular}

Anahtar kelimeler:

Kentsel yeşil alanlar

Ekolojik sürdürülebilirlik

3B gölge analizi

Amasya Üniversitesi Hâkimiyet Yerleşkesi

Amasya

\section{Keywords:}

Urban green areas

Ecological sustainability

3D shadow analysis

Amasya University Hâkimiyet Campus

Amasya

\begin{abstract}
Özet
Çalışmada; küçük ölçekte kent modeli olarak değerlendirilen üniversite yerleşkesi ele alınarak Amasya ili Merkez ilçe sınırları içerisinde yer alan Amasya Üniversitesi Hâkimiyet Yerleşkesi çalışma alanı olarak seçilmiştir. Çalışmanın amacı Hâkimiyet Yerleşkesi'nde yer alan eğitim ve idari binaların yeşil alanlar üzerinde oluşturdukları gölge süresi uzunlukları doğrultusunda yerleşke yeşil alanlarında kullanılan bitkilerin ışık-gölge-su isteklerine göre bitki tür seçiminin doğru olup olmadığını tespit ederek yerleşkelerin ekolojik sürdürülebilirliğe ve kent ekosistemine olan katkısını belirlemektir. Bu amaç doğrultusunda öncelikle literatür taraması ile arazi çalışması yapılarak yerleşkede bulunan bitki türleri tespit edilerek farklı açılardan fotoğraf çekimi yapılmıştır. Hâkimiyet Yerleşkesi'nde bulunan 3 eğitim binası ve 3 idari bina CityEngine yazılımı kullanılarak, prosedürel modelleme teknikleriyle 3 boyutlu (3B) olarak modellenmiştir. 3B Kampüs modeli, Sketchup Pro 2019 programına aktarılarak, yılın farklı aylarına göre 3B gölge analizi yapılmıştır. Elde edilen bulgular ışığında Hâkimiyet Yerleşkesi'ndeki binaların oluşturduğu gölge sürelerinin Aralık ve Ocak aylarında daha fazla, Haziran ve Temmuz aylarında ise daha az olduğu görülmektedir. Yerleşkenin 392-400 m. ile 410-420 m. kotları arasında yerleşke sınırlarında yer alan her dem yeşil ağaç ve ağaççıklar ile çalı gruplarının binaların oluşturduğu gölgeden olumsuz etkilenmediği, 400-410 m. kot aralığında bina yakın çevrelerinde yer alan yaprağını döken ağaç ve ağaççık bitki türleri ile çalı gruplarının ise bu durumdan olumsuz etkilendiği belirlenmiştir. Bulgular dâhilinde yerleşkenin ekolojik sürdürülebilirliğinin sağlanmasına yönelik önerilerde bulunulmuştur.
\end{abstract}

\begin{abstract}
The Amasya University Hâkimiyet Campus, located within the central district of Amasya, was chosen as the study area. The university campus was considered as a small-scale urban model. The aim of the study was to determine whether the plant species selection was correct according to the lightshadow-water requirements of the plants used in the green areas of the campus and in line with the duration of the shadows cast on the green areas of the educational and administrative buildings of the Hâkimiyet Campus and also to determine the contribution of the campus to ecological sustainability and the urban ecosystem. To this purpose, the plant species in the campus were identified by first carrying out a literature review and a field study and then taking photographs from different angles. Three educational buildings and three administrative buildings on the Hâkimiyet Campus were modeled in three-dimension (3D) using procedural modeling techniques via CityEngine software. The 3D campus model was transferred to the Sketchup Pro 2019 program and a 3D shadow analysis was performed according to different months of the year. The findings indicated that the shadows cast by the buildings on the Hâkimiyet Campus persisted for a longer time in December and January, and a shorter time in June and July. Evergreen trees, shrubs, and bush groups located on the boundaries of the campus at the elevations of 392-400 and $410-420 \mathrm{~m}$ were not adversely affected by the shadows of the buildings; however, those located in the vicinity of the buildings at the elevation range of $400-410 \mathrm{~m}$ were negatively affected by this situation. Within the scope of the findings, recommendations were made to ensure the ecological sustainability of the campus.
\end{abstract}

\section{GiRiş}

Sanayi Devrimi ile birlikte teknolojinin gelişmesi, kırdan kente göç olaylarının artmasına bağlı olarak nüfus artışı ve kentleşme hareketleri paralelinde kentler plansız ve altyapıdan yoksun bir şekilde gelişim göstermektedir. Bu olayların dâhilinde kentlerde betonlaşma oranı artarken yeşil alanlar (yol ağaçları, kent ormanları, yerleşkeler, tarım alanları, yeşil çatılar vb.) konut yapımı, yol yapımı vb. nedenlerden dolayı tahrip edilerek miktarı azalmaktadır. Bu durum ekosistemin bozulmasına, küresel ısınmanın artmasına, ozon deliğinin büyümesine, 
çevre kirliliğinin ve kimyasal atıkların artmasına yol açmaktadır.

Doğal kaynakların tüketiminin zamanla artması ve üretimin yetersiz olması sebebiyle sınırlı olan doğal kaynakların bir gün tükeneceği bilinerek devamlılıklarının sağlanması adına dünyanın birçok yerinde ciddi çözüm arayışlarına girilmiştir. Bu kapsamda doğa-insan-toplum bütününde sağlıklı bir döngünün sağlanması adına çevreyle uyumlu sürdürülebilirlik politikası gündeme gelmiştir.

Yeni kentleşme konseptinde kentlerin sürdürülebilir gelişiminin sağlanması adına atık tüketiminin azaltılması, yenilenebilir enerji kaynaklarının kullanımı, motorsuz ulaşım sisteminin kullanılması oldukça önemlidir (Kurt Konakoğlu ve Usta 2019).

Sürdürülebilirlik kavramının çıkış noktası, ekonomik ve teknolojik gelişmelere paralel bir şekilde ortaya çıkan çevre sorunlarının önüne geçebilme ve ekosistemlerin korunması üzerine olup kavramın temeli belirli bir seviyede tutulabilme yeteneğidir. Sürdürülebilirlik kelimesinin kökeni Türkçe'de 'korumak, aşağıdan desteklemek' anlamlarına gelen Latince 'sustenir' kelimesine dayanmaktadır (Muscoe 1995). Sürdürülebilirlik kavramı literatürde farklı şekillerde tanımlansa da genel olarak, güncel intiyaçları gelecek kuşakların kendi intiyaçlarını karşılama olanaklarına zarar vermeden karşılamak şeklinde ifade edilmektedir (McDonough 1992).

Sürdürülebilirlik kavramı ekolojik (çevresel), ekonomik ve sosyal (toplumsal) boyutları kapsayan bütünsel bir yaklaşımdır. Sürdürülebilirlikte sadece ekolojik (çevresel) boyutun dengesini sağlamak olmamalı, ekonomik ve sosyal boyutların da dengeli bir şekilde birleştirilip döngünün tamamlanması sağlanmalıdır (Sılaydın 2006, Turgut 2014, Vural 2016). Ekolojik sürdürülebilirlik, yeryüzünde yaşamı destekleyen ekolojik süreçlerin, biyolojik çeşitliliğin ve doğal kaynakların korunması ve sürdürülebilir kullanımıdır (Costanza 1999). Başka bir tanıma göre, kaynakların tutumlu kullanılmasını, yenilenebilir enerji kaynaklarının tercih edilmesini ve ekosistemlerin korunumunu içermektedir (Cole 1999). Sosyal sürdürülebilirlik kavramı sosyal eşitlik, yaşanabilirlik, toplum gelişimi, sosyal sermaye, sosyal destek, sosyal sorumluluk, kültürel yeterlilik, yaşam kalitesi ve insan adaptasyonu gibi konuları kapsamaktadır. Sürdürülebilirliğin tüm alanları sosyal ve doğal çevre arasındaki ilişkiye bağlı olduğu için sosyal sürdürülebilirlik tüm insan faaliyetlerini kapsamaktadır
(URL-1 2020). Kavram, sürdürülebilirliğin ekolojik ve ekonomik boyutlarına kıyasla sonraki zaman diliminde ortaya çıkmıştır (Colantonio and Dixon 2011). Sürdürülebilirlik kavramının ekonomik boyutu tükenme potansiyeli olan kaynakların korunmasını ve bozulmasının engellenmesi olarak ifade edilmektedir (Goodland 2002, Vivien 2008). Bu nedenle sürdürülebilirlik kavramı her zaman yenilenebilir enerji kaynakları ekonomisinin merkez unsuru olmuştur (Vivien 2008).

Üniversiteler, çevresel sorunların çözümünde ve toplum bilincinin arttırımasında etkin rol oynamaktadır. Üniversitelerde çevre üzerinde baskı unsuru olarak görüldüğü için kent ekosistemine doğrudan ya da dolaylı olarak zarar vermektedir. Bu anlayışla, çevreye duyarlı, enerji etkin yöntemleri kullanabilen sürdürülebilir yerleşke tasarımları yaygınlaşmaya başlamışır.

Sürdürülebilir yerleşke, dünyada ve ülkemizde ülke ekonomisini ve doğayı korumak üzere enerji tasarrufu sağlayan çevreye duyarlı planlama yaklaşımları ile ortaya çıkmıştır (UNEP 2013). Bu kapsamda sürdürülebilirlik kavramından yola çıkılarak kendi faaliyetlerini gerçekleştirebilen, kendi kendine yetebilen, sosyal ve ekonomik açıdan ortaya çıkabilecek olumsuzlukları tolere edebilen sürdürülebilir yerleşke yaklaşımı ortaya çıkmıştır (Günerhan ve Günerhan 2016). Sürdürülebilir yerleşke kavramının ana amacı başlangıçta öğrenci, idari ve akademik personelin çevre bilincinin arttırılması iken daha sonraları üniversite yerleşkelerindeki binaların enerji verimliliğini arttırmak, karbon salınımını minimuma indirgemek, atık suların ve katı atıkların yönetimi şeklinde olmuştur (Orr 2010).

Sürdürülebilir yerleşke; yeşil yerleşke, yeşil kampüs, yeşil üniversite, çevre dostu yerleşke, eko-kampüs olarak ta adlandırılmaktadır (Güler 2001). Sürdürülebilir yerleşkeler ekolojik (çevresel), sosyal ve ekonomik etkilerin en aza indirilmesini hedeflemekte ve bu bilinci çevresine aşılamaktadır (Günerhan ve Günerhan 2016). Sürdürülebilir yerleşkelerde birinci hedef doğal kaynakların akılcı kullanımı, ikinci hedef uzun vadede devamlılığının sağlanması, üçüncü hedef ise konumlandırılıkları kente örnek teşkil etmeleridir (Büyükkurt 2019). Üniversite yerleşkeleri günümüzde karşılaştığımız sorunların çözümünde önemli rol oynamaktadır (Günerhan ve Günerhan 2016).

Üniversitelerde sürdürülebilirlik fikrinin hayata geçirilmesiyle birlikte enerji verimliliğinin arttırıldığı, su ve enerji etkin tasarımların yapılmaya başlandığı, yağmur suyu ve atık suların yeniden kullanıldığı, yeşil binalar ile 
yenilenebilir enerji odaklı tasarımlara yer verildiği görülmektedir (Özdal Oktay ve Özyılmaz Küçükyağcı 2015, Büyükkurt 2019). Yerleşkelerde sürdürülebilirliği sağlamak adına yağmur suyu ve atık sularını değerlendirmek, enerji verimliliğinin arttırıldığı yenilenebilir enerji odaklı tasarımları yerleşke planlamasına dâhil etmek, yerleşkelerde iklim ve toprak koşullarına uygun bitki türlerini kullanmak gerekmektedir. Böylelikle sürdürülebilir bütüncül bir yaklaşım sağlanmış olur (Güllü, Köksal ve Şengül 2012, Büyükkurt 2019).

Çalışmada, Amasya Üniversitesi Hâkimiyet Yerleşkesi'nde yer alan eğitim ve idari binaların yeşil alanlar üzerinde oluşturdukları gölge süresi uzunlukları doğrultusunda yerleşke yeşil alanlarında kullanılan bitkilerin ışık-gölge-su isteklerine göre bitki tür seçiminin doğru olup olmadığını tespit ederek yerleşkenin ekolojik sürdürülebilirliğe ve kent ekosistemine olan katkısını belirlemek ele alınmıştır.

\section{MATERYAL VE YÖNTEM}

Çalışmada arazi çalışmalarının gerçekleştirildiği Amasya ili Merkez ilçe sınırları içerisinde yer alan Amasya Üniversitesi Hâkimiyet Yerleşkesi araştırmanın ana materyalini oluşturmaktadır. Çalışma alanını tanımlayan Amasya Belediyesi'nden elde edilen 2020 yılına ait hâlihazır harita, yerleşkeler için hazırlanan stratejik planlar, master planlar, arazi çalışmalarına ait gözlemler, arazi çalışmaları sırasında farklı zaman aralıklarında alınan görüntüler, Google Earth görüntüsü araştırmada kullanılan diğer materyallerdir. Araştırma alanı için veri elde etmede kullanılan ArcGIS 10.5, Sketchup Pro, Photoshop CS6 programları da yararlanılan materyaller arasındadır.

Çalışma alanı olarak seçilen Amasya Üniversitesi Hâkimiyet Yerleşkesi 53.129,79 $\mathrm{m}^{2}$ büyüklüğünde olup yerleşkede Eğitim Fakültesi A-B-C Blok, konferans salonu, merkez kütüphane binası, Rektörlük binası ve spor sahaları bulunmaktadır (Şekil 1). Yerleşke Amasya kent merkezine yürüme mesafesindedir. Yerleşkeden kent merkezine motorlu araçla ulaşım yaklaşık 7 dakikada sağlanmaktadır.

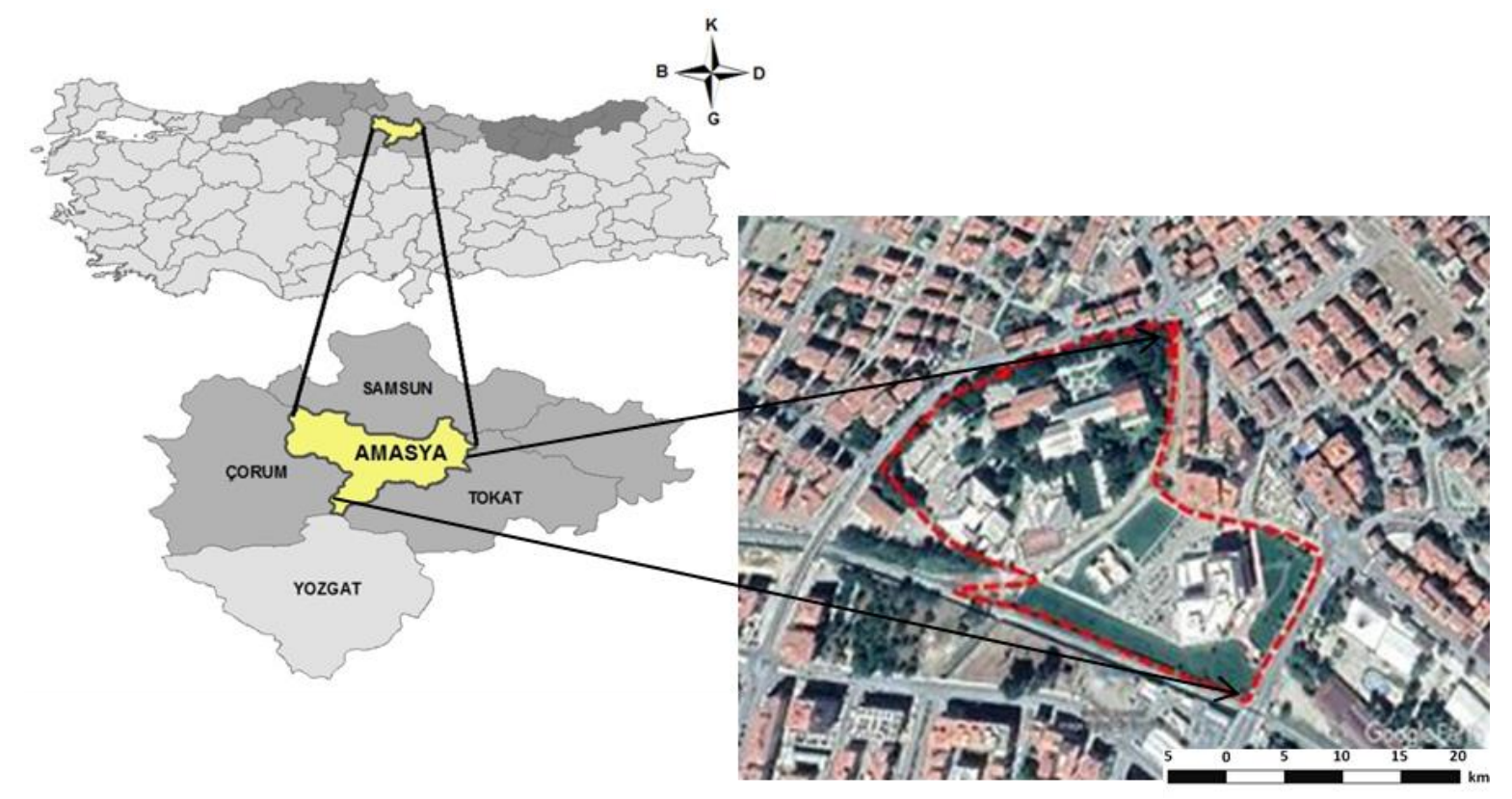

Şekil 1. Amasya Üniversitesi Hâkimiyet Yerleşkesi çalışma alanı sınırları

Çalışma kapsamında envanter ve arazi çalışması yapılarak yerleşkede bulunan bitki türleri tespit edilmiş ve farklı açılardan fotoğraf çekimi yapılmıştır. Arazi çalışması sırasında belirlenen mevcut bitki türleri için bitki kimlik kartları oluşturulmuştur. Daha sonra, Hâkimiyet Yerleşkesi'nin CBS ortamında Arcgis 10.5 programı kullanılarak bakı, yükseklik ve yeşil alan analizleri gerçekleştirilmiştir. Hâkimiyet Yerleşkesi'nde bulunan 3 eğitim binası (Eğitim Fakültesi A-B-C Blok) ve 3 idari bina (konferans salonu, merkez kütüphane binası, Rektörlük binası) CityEngine yazılımı kullanılarak, prosedürel modelleme teknikleriyle 3 boyutlu (3B) olarak modellenmiştir. Modelleme yapmak için CGA (Computer Generated Architecture) şekil dili kullanılmıştır. 3B Kampüs modeli, Sketchup Pro 2019 programına aktarılarak, yılın 12 ayı için 3B gölge analizi yapılmıştır. 3B gölge analizi için Sketchup programının 'Shadow Analysis' eklentisi kullanılmıştır. Böylelikle, yerleşkelerde yer alan 
eğitim ve idari binaların yıl içerisinde farklı zaman aralıklarında yapmış oldukları gölge süresi uzunlukları belirlenerek yerleşke yeşil alanlarında yer alan bitki türlerinin yılda ortalama kaç saat güneş ışığı aldıkları tespit edilmiştir. Sketchup Pro 2019 programında 3B gölge analizi gerçekleştirilirken 12 ay için de güneş ışınlarının dik geldiği saat esas alınmıştır. Elde edilen bulgular ışığında Hâkimiyet Yerleşkesi'ndeki binaların oluşturduğu gölge sürelerinin Aralık ve Ocak aylarında daha fazla, Haziran ve Temmuz aylarında ise daha az olduğu görülmektedir.

Çalışmada izlenen süreç Şekil 2'de özetlenmiştir.

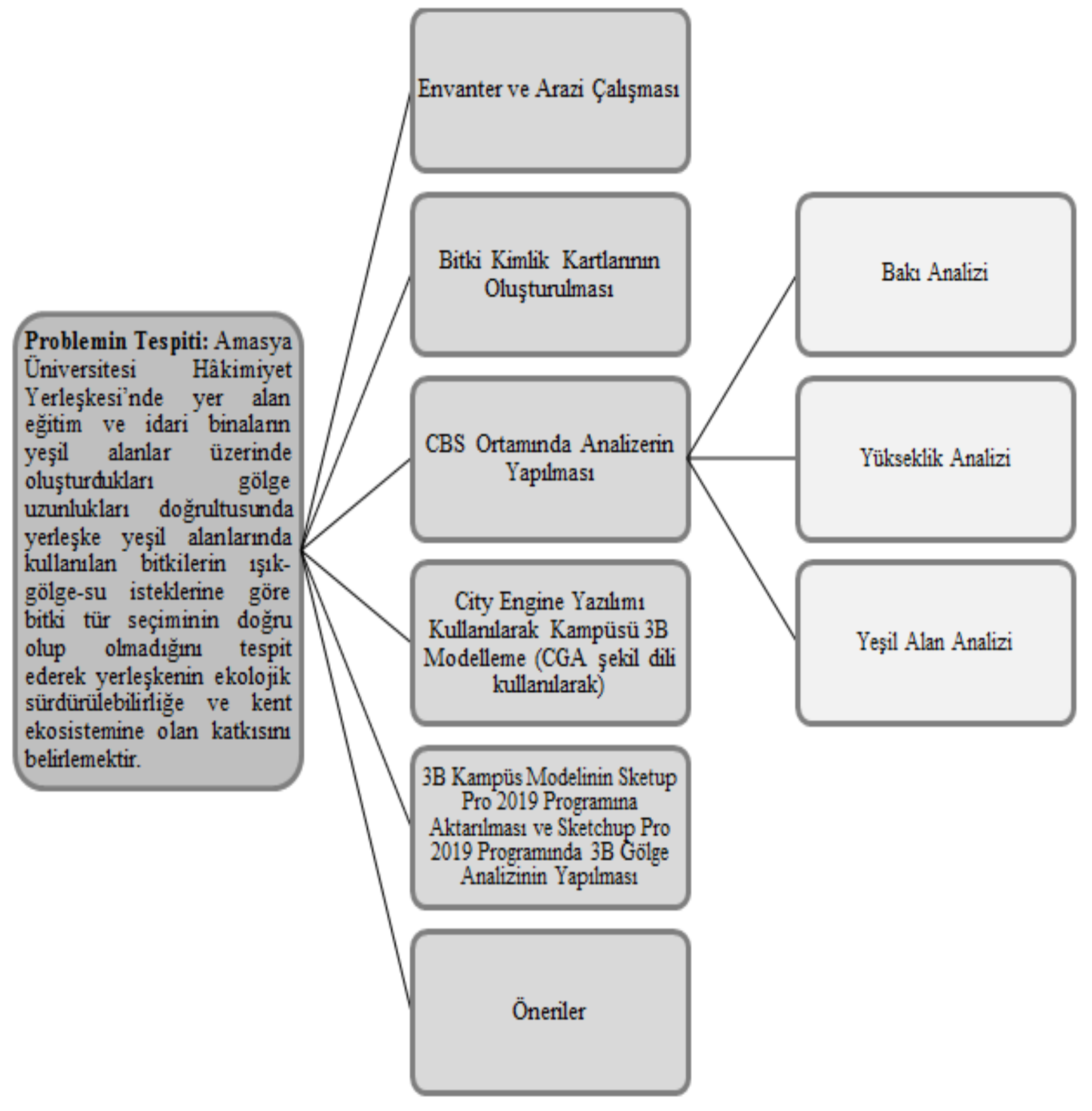

Şekil 2. Çalışmanın iş-akış şeması

\section{BULGULAR}

\section{Envanter ve arazi çalışması ile ilgili bulgular}

Çalışma kapsamında farklı gün ve saatlerde gerçekleştirilen yerinde gözlemler ile arazi çalışmalarına göre yerleşkede 16 adet yaprağını döken ağaç ve ağaççık, 7 adet yaprağını dökmeyen her dem yeşil ağaç ve ağaç̧̧ı, 5 adet çalı olmak üzere 28 adet farklı bitki türü tespit edilmiştir (Çizelge 1). 
Çizelge 1. Amasya Üniversitesi Hâkimiyet Yerleşkesi'nde yer alan bitki türleri

\begin{tabular}{|c|c|c|c|c|}
\hline & atince Adı & Türkçe Adı & Gölge İsteği & Su İsteği \\
\hline \multirow{16}{*}{ 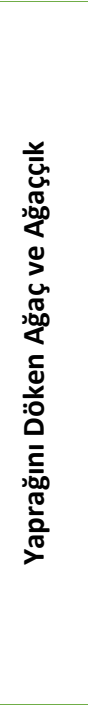 } & Albizzia julibrissin & Gülibrişim & Güneşli ve yarı gölgeli alanlar & Orta \\
\hline & Cercis siliquastrum & Erguvan & Güneşli ve yarı gölgeli alanlar & $\mathrm{Az}$ \\
\hline & Robinia pseudacacia & Yalancı Akasya & Güneşli alanlar & $\mathrm{Az}$ \\
\hline & Salix babylonica & Salkım Söğüt & Güneşli alanlar & Çok \\
\hline & Tilia cordata & Ihlamur & Güneşli alanlar & Çok \\
\hline & Quercus robur & Meşe & Güneşli ve yarı gölgeli alanlar & Çok \\
\hline & Prunus ceracifera Pissardii Nigra & Süs Eriği & Güneşli alanlar & Orta \\
\hline & Malus floribunda & Süs Elması & Güneşli ve yarı gölgeli alanlar & Çok \\
\hline & Catalpa bignonioides & Katalpa & Güneşli ve yarı gölgeli alanlar & Orta \\
\hline & Paulownia tomentosa & Tüylü Pavlonya & Güneşli ve yarı gölgeli alanlar & Çok \\
\hline & Acer campeste & Ova Akçaağacı & Güneşli alanlar & Orta \\
\hline & Acer platanoides & Çınar Yapraklı Akçaağaç & Güneşli ve yarı gölgeli alanlar & Orta \\
\hline & Acer negundo & Dişbudak Yapraklı Akçaağaç & Güneşli, yarı gölgeli ve gölgeli alanlar & Orta \\
\hline & Morus nigra 'Pendula' & Sarkık Siyah Dut & Güneşli ve yarı gölgeli alanlar & Orta \\
\hline & Juglans regia & Adi Ceviz & Güneşli alanlar & Orta \\
\hline & Platanus orientalis & Doğu Çınarı & Güneşli alanlar & Orta \\
\hline \multirow{7}{*}{ 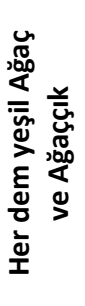 } & X Cupressocyparis leylandii & Yalancı Melez Servi & Güneşli ve yarı gölgeli alanlar & Orta \\
\hline & Cupressus macrocorpa & Limoni Servi & Güneşli, yarı gölgeli ve gölgeli alanlar & $\mathrm{Az}$ \\
\hline & Calocedrus decurrens & Kalifornia Su Sediri & Güneşli alanlar & Çok \\
\hline & Pinus nigra & Kara Çam & Güneşli alanlar & Orta \\
\hline & Pinus sylvestris & Sarı Çam & Yarı gölgeli alanlar & Orta \\
\hline & Cedrus atlantica & Atlas Sediri & Güneşli alanlar & Orta \\
\hline & Picea pungens 'Hoopsi' & Boncuk Mavisi Ladin & Güneşli ve yarı gölgeli alanlar & Orta \\
\hline \multirow{5}{*}{ 心 } & Nerium olaender & Zakkum & Güneşli ve yarı gölgeli alanlar & $\mathrm{Az}$ \\
\hline & Rosa chinensis & Çin Gülü & Güneşli ve yarı gölgeli alanlar & Orta \\
\hline & Ligustrum ovalifolium 'Hassk.' & Minyatür Yapraklı Kurt Bağrı & Güneşli ve yarı gölgeli alanlar & Orta \\
\hline & Euonymus japonicus & Taflan & Yarı gölgeli alanlar & Orta \\
\hline & Buxus sempervirens & Adi Şimşir & Güneşli, yarı gölgeli ve gölgeli alanlar & Orta \\
\hline
\end{tabular}

Bitkilerin yerleşke içerisinde nerede oldukları Google Earth görüntüsü üzerine işlenerek Şekil 3’te belirtilmiştir.

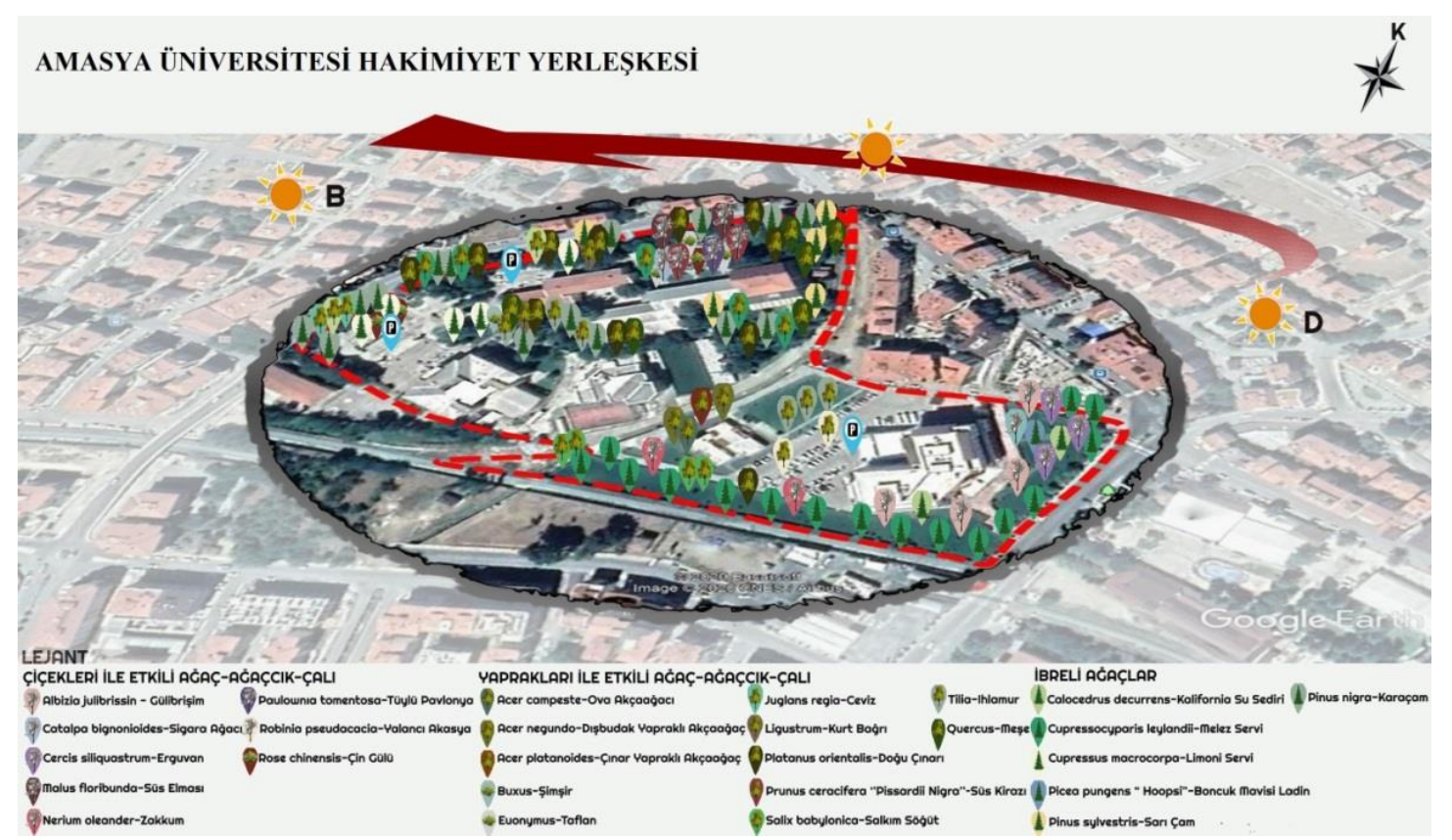

Şekil 3. Amasya Üniversitesi Hâkimiyet Yerleşkesi'nde yer alan bitki türlerinin lokasyonu 


\section{Bitki kimlik kartlarının oluşturulması ile ilgili bulgular}

Arazi çalışmaları sırasında yerleşkede belirlenen 28 adet farklı bitki türü için bitkilerin familya-botanik ismi, tipiformu, boyu-rengi, yetişme koşulları, estetik özelliği, fonksiyonel özelliği, bitkinin görseli ve bitkinin yerleşke içerisinde nerede olduğunu gösteren haritanın yer aldığı kimlik kartları oluşturulmuştur. Her bir bitki türü için oluşturulan kimlik kartlarından örnekler Şekil 4'te verilmiştir.
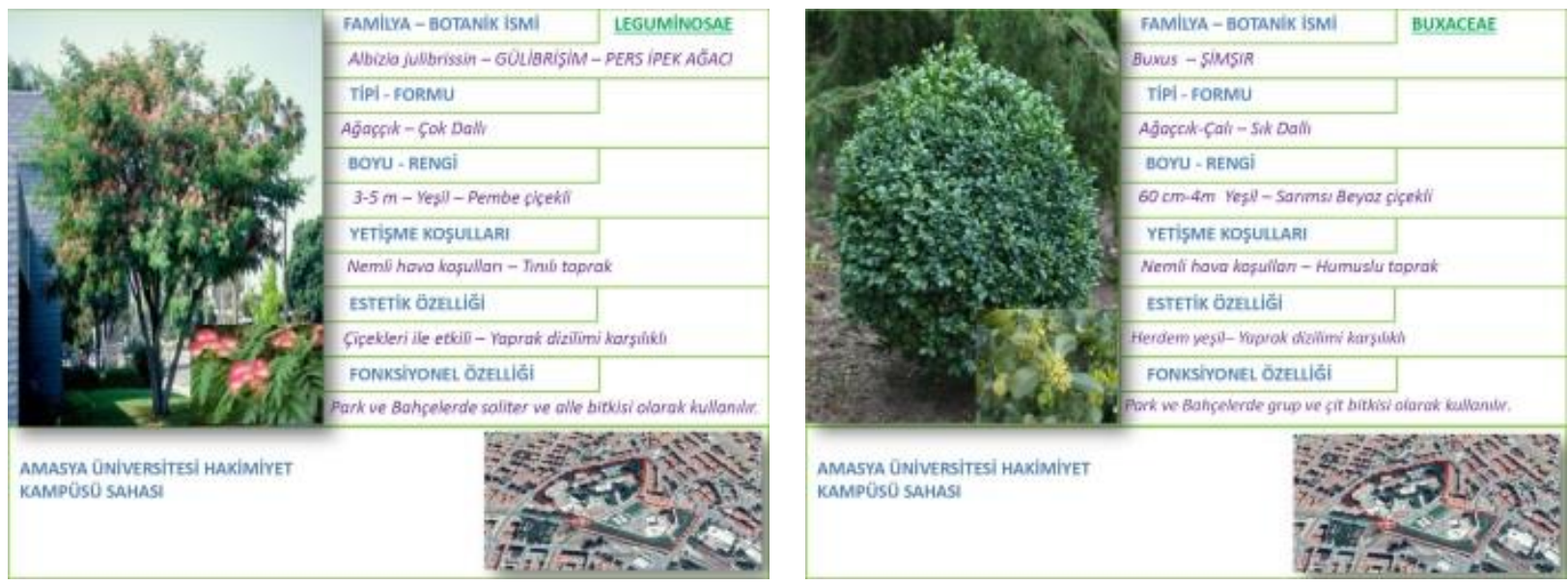

Şekil 4. Amasya Üniversitesi Hâkimiyet Yerleşkesi’nde yer alan her bir bitki türü için oluşturulan bitki kimlik kartlarından örnekler

\section{CBS ortamında yapılan analizler ile ilgili bulgular}

Amasya Üniversitesi Hakimiyet Yerleşkesi'nin CBS ortamında ArcGIS 10.5 programında bakı, yükseklik ve yeşil alan analizleri gerçekleştirilmiştir.

Hem yerleşkede yer alan binaların hem de mevcut bitkilendirme tasarımının güneşe uygun konumlandırılıp konumlandırımadığını ve arazide bulunan yüzeylerin bakış yönlerini belirlemek amacıyla bakı analizi gerçekleştirilmiştir. Yerleşkenin bakı analizine göre; eğitim binaları (Eğitim Fakültesi A-B-C Blok) ile idari binaların (konferans salonu, merkez kütüphane binası, Rektörlük binası) yakın çevrelerinin çoğunlukla açık mavi ve yeşil renkle ifade edilen güney-güneydoğu ve sarı ve turuncu renkle ifade edilen doğu-kuzeydoğu yönünde yer aldığı görülmektedir (Şekil 5). Bina yakın çevrelerinde daha çok çalı gruplarının, yerleşke sınırlarında da her dem yeşil ağaç ve ağaççıklar ile çalı gruplarının, binaların gölgelerinin düştüğü yerlerde ise yaprağını döken ağaç ve ağaçı̧ıkların yer aldığı görülmektedir.

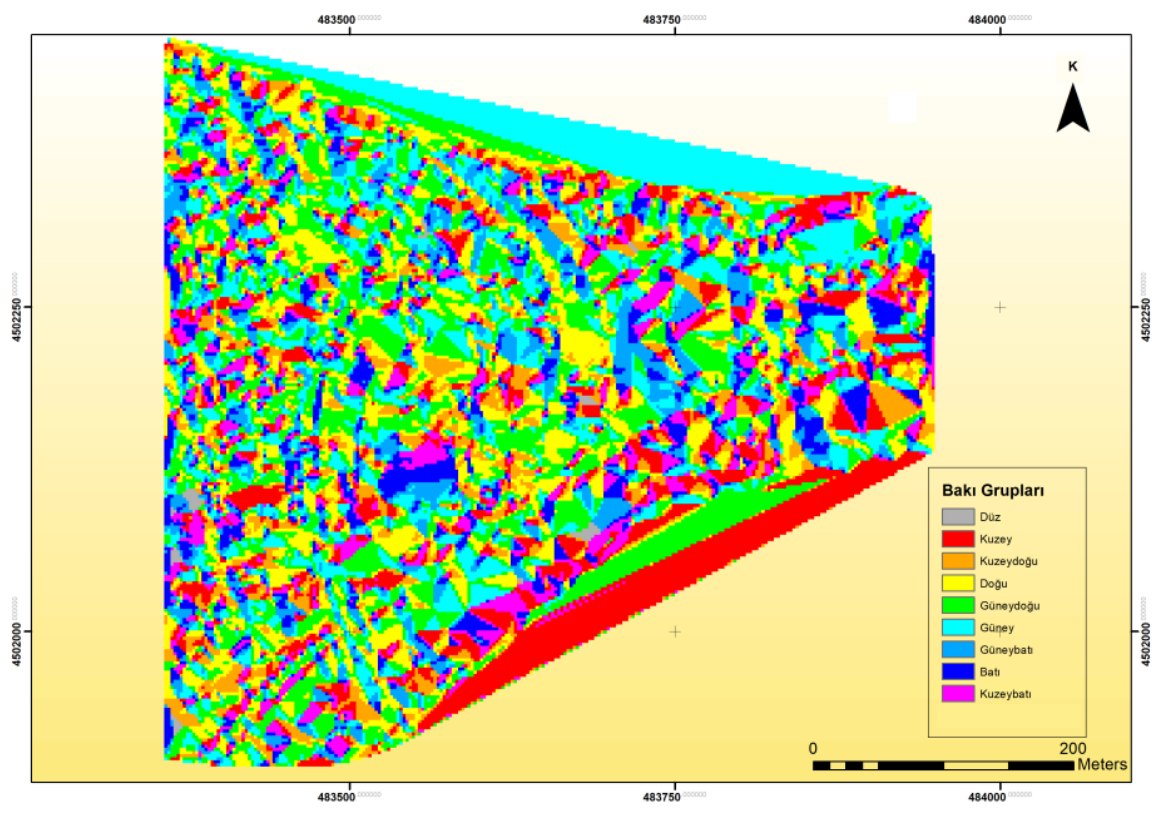

Şekil 5. Amasya Üniversitesi Hâkimiyet Yerleşkesi bakı analizi 
Artvin Çoruh Üniversitesi

Orman Fakültesi Dergisi ISSN:2146-1880, e-ISSN: 2146-698X Yıl: 2020, Cilt: 21, Sayı:2, Sayfa:XXX

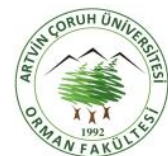

ofd.artvin.edu.t
Artvin Coruh University

Journal of Forestry Faculty

ISSN:2146-1880, e-ISSN: 2146-698X

Year: 2020, Vol: 21, Issue: 2, Pages:XXX

\section{(c) (1)}

Yükseklik analizine göre, yerleşkenin en düşük noktası Rektörlük binası ile anayol bağlantısını sağlayan kot değeri 392 m., en yüksek noktası ise eğitim (Eğitim Fakültesi A-BC Blok) ve idari binaların (merkez kütüphane binası,
Rektörlük binası) en üst kotu olan 436 m.'dir. Yerleşkede yeşil alanlar 392-420 m kot aralığında yer almaktadır (Şekil 6). Yerleşkenin en düşük ve en yüksek noktaları arasında $28 \mathrm{~m}$. yükseklik farkı bulunmaktadır.

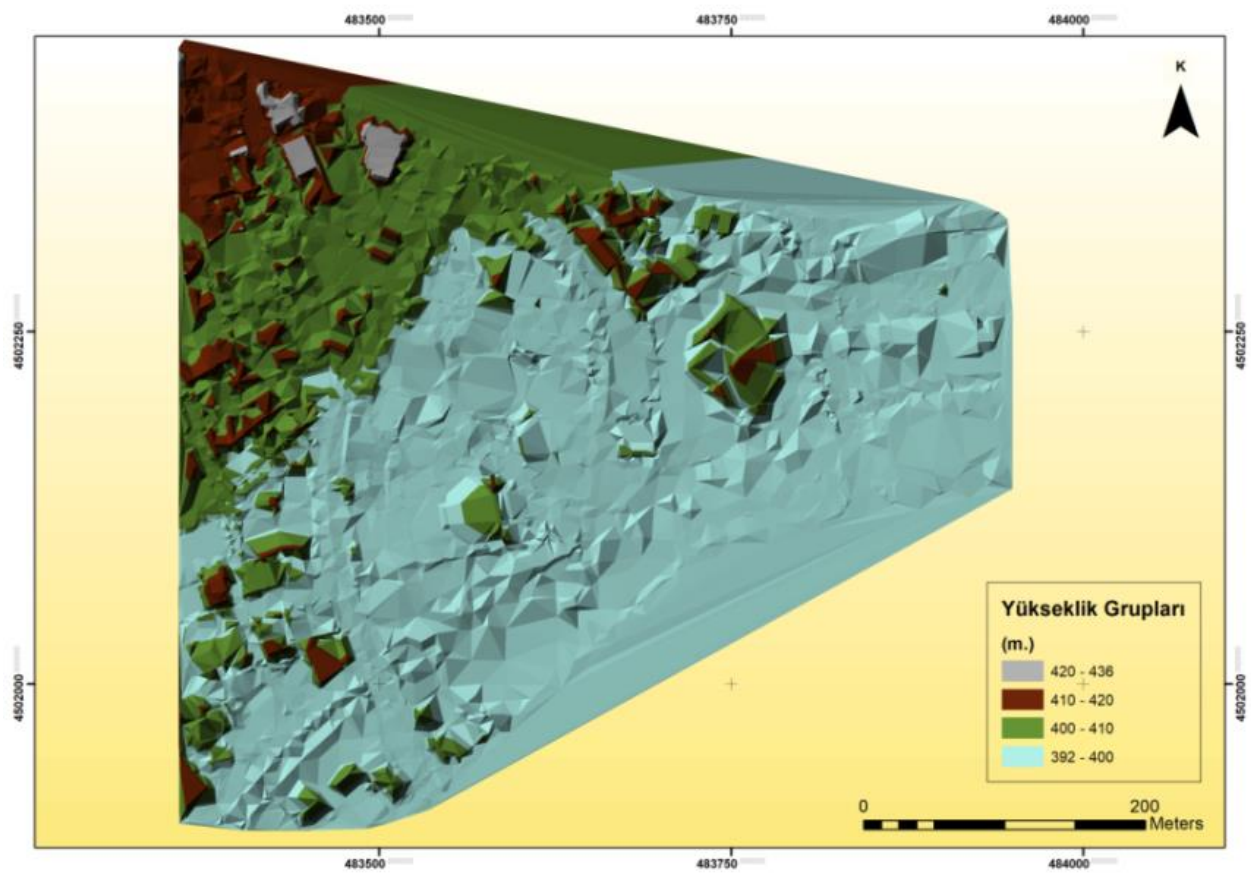

Şekil 6. Amasya Üniversitesi Hâkimiyet Yerleşkesi yükseklik analizi

Yeşil alan analizine göre; yerleşkede $392-400 \mathrm{~m}$. kot aralığında serbest çim alanlar, 400-410 m. kotları arasında yaprağını döken ağaç ve ağaççı, çalı ile her dem yeşil Cupressus macrocorpa, Picea pungens 'Hoopsi' bitki türleri, 410-420 m. kotları arasında her dem yeşil ağaç ve ağaç̧̧ı Cupressocyparis leylandii, Calocedrus decurrens, Pinus nigra, Pinus sylvestris, Cedrus atlantica bulunmaktadır (Şekil 7-9).

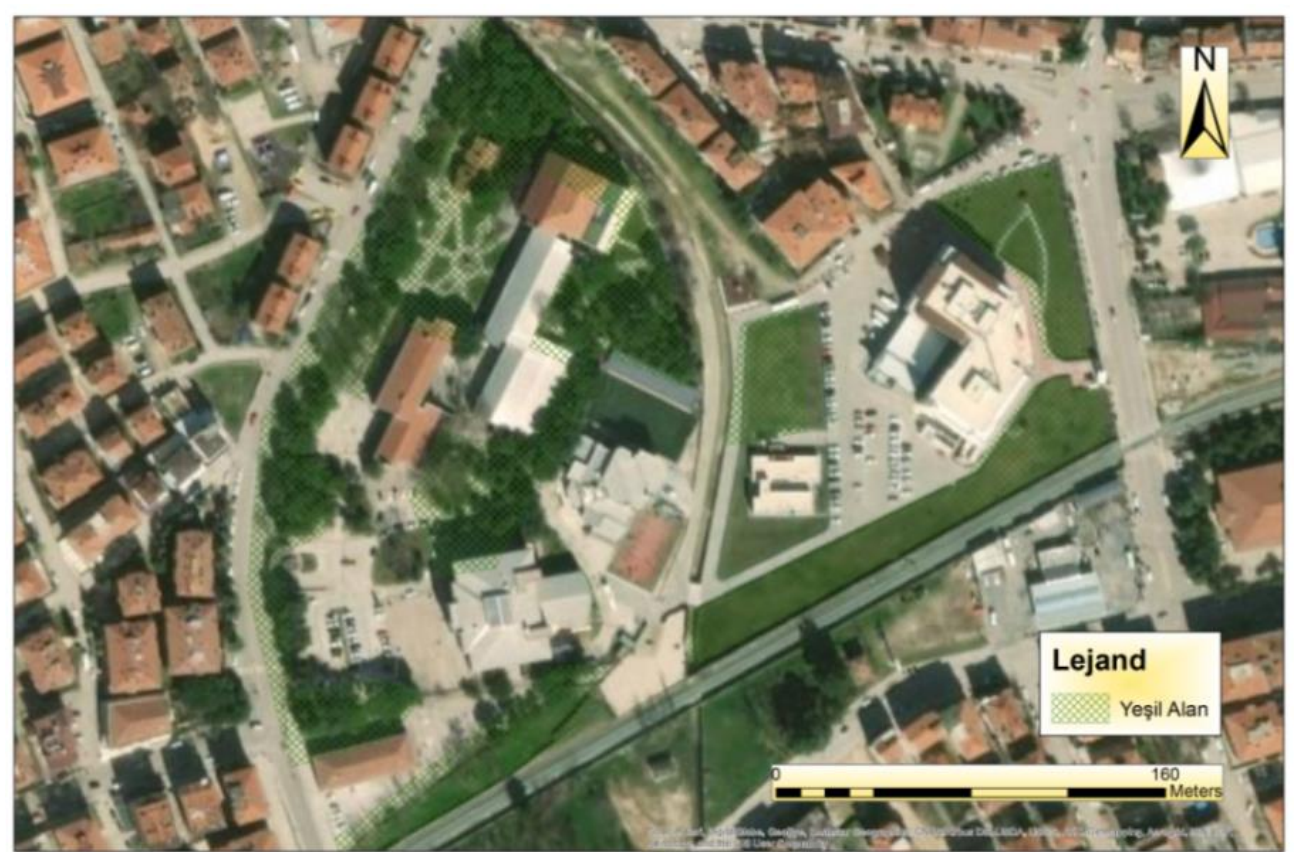

Şekil 7. Amasya Üniversitesi Hâkimiyet Yerleşkesi yeşil alan analizi 

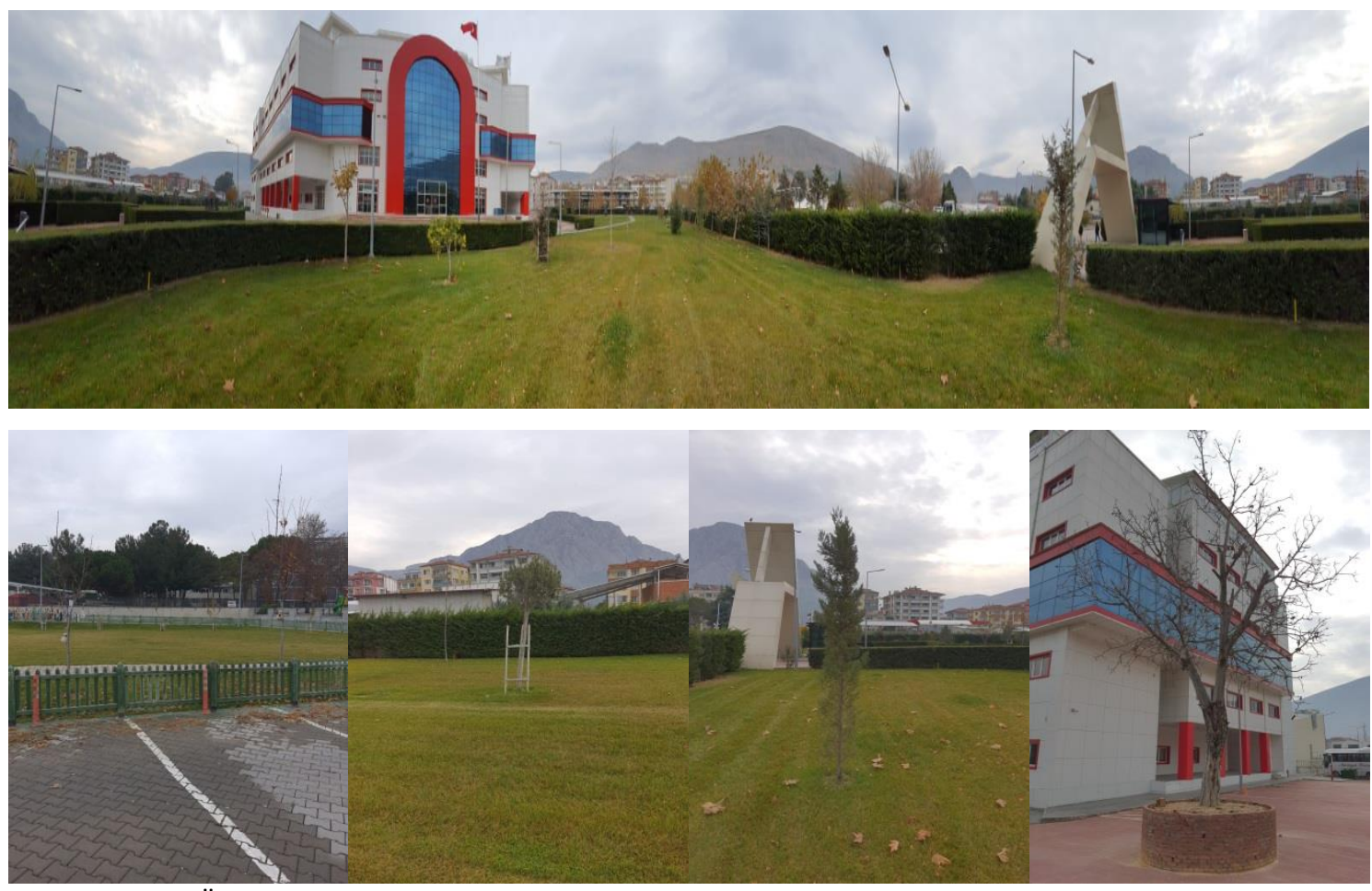

Şekil 8. Amasya Üniversitesi Hâkimiyet Yerleşkesi 392-400 m. kot aralığındaki bitki kompozisyonlarından görünümler
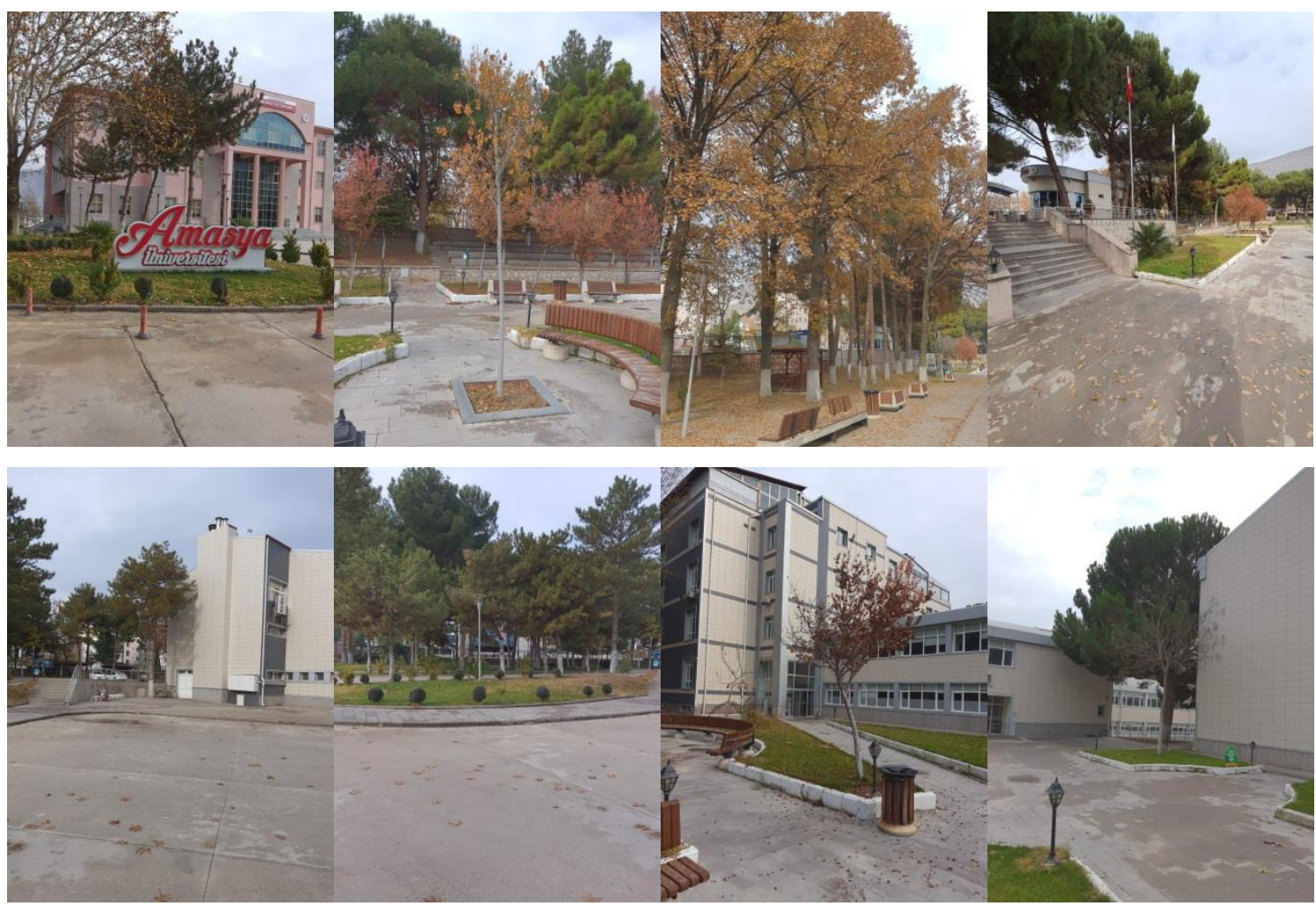

Şekil 9. Amasya Üniversitesi Hâkimiyet Yerleşkesi 400-420 m. kot aralığındaki bitki kompozisyonlarından görünümler

\section{B Gölge Analizi ile ilgili bulgular}

Hâkimiyet Yerleşkesi'nde bulunan 3 eğitim binası (Eğitim Fakültesi A-B-C Blok) ve 3 idari bina (konferans salonu, merkez kütüphane binası, Rektörlük binası) CityEngine yazılımı kullanılarak, prosedürel modelleme teknikleriyle
3 boyutlu (3B) olarak modellenmiş ve Sketchup Pro 2019 programına aktarılarak, yılın 12 ayı için güneş ışınlarının dik geldiği saat esas alınarak 3B gölge analizi yapılmıştır (Şekil 10). Şekil 10'da sarı renkle ifade edilen bölgelerin gölge süresinin en az, koyu mavi renkle ifade edilen bölgelerin ise gölge süresinin en uzun olduğu anlamına 
gelmektedir. 3B gölge analizine göre; her ay yerleşkelerde yer alan binaların yakın çevrelerinde gölgelenme süresinin en uzun olduğu, 12 ay içerisinde de Aralık ve
Ocak aylarında gölgelenme süresinin fazla, Haziran ve Temmuz aylarında ise gölgelenme sürelerinin diğer aylara göre daha az olduğu görülmektedir.

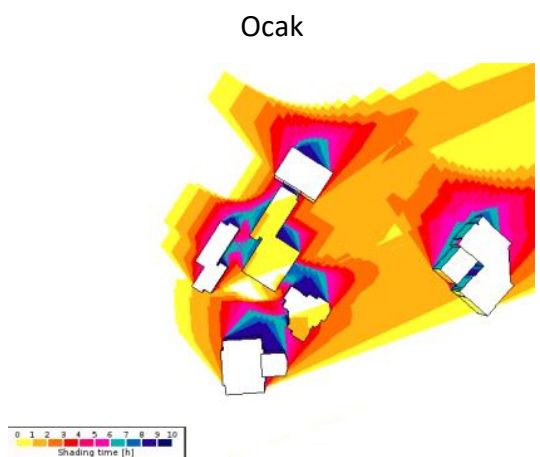

Nisan

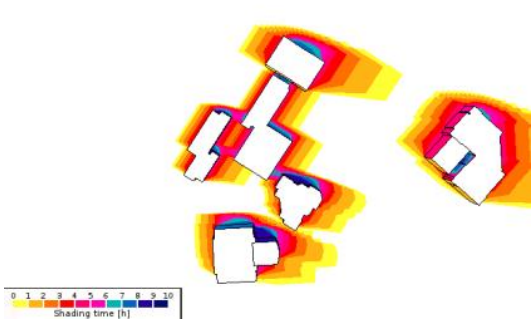

Temmuz

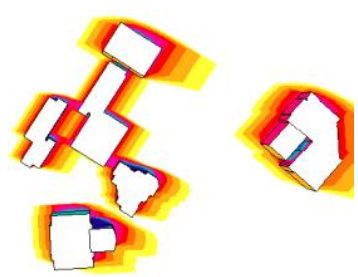

Ekim

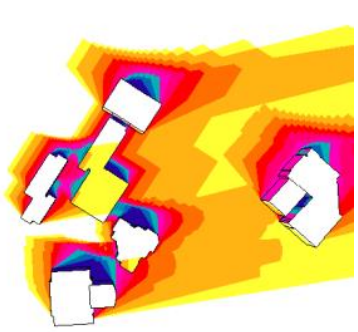

0

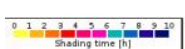

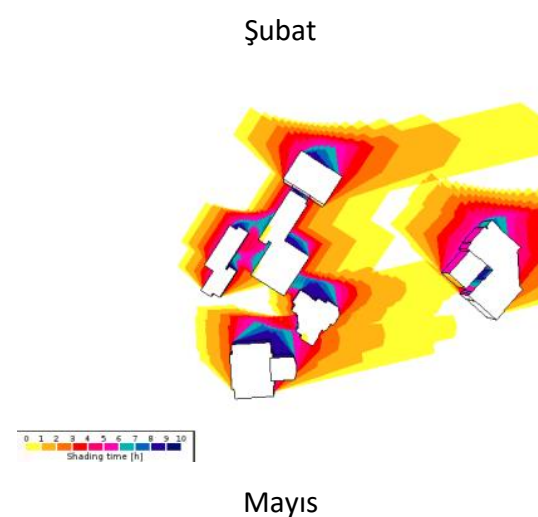

Mayıs
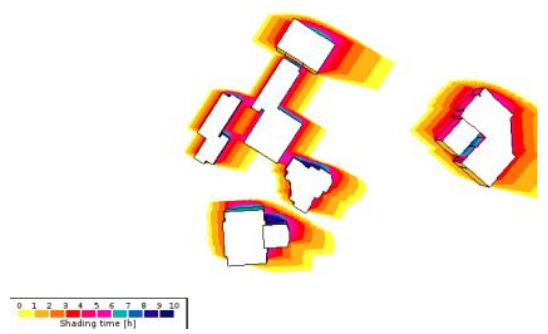

Ağustos

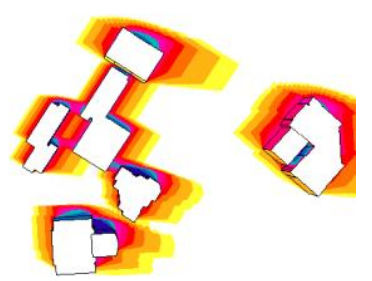

Kasım
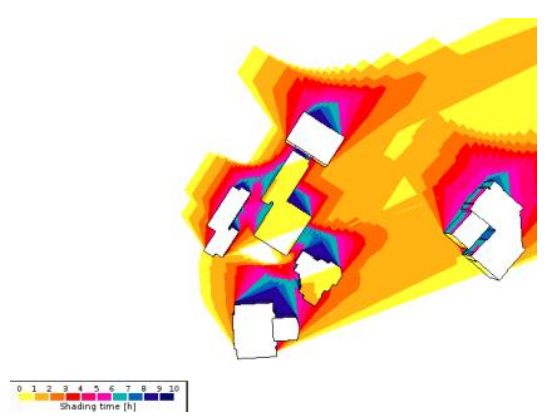

Mart

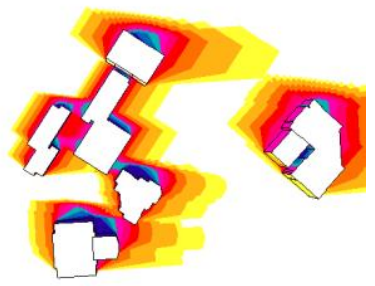

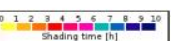

Haziran

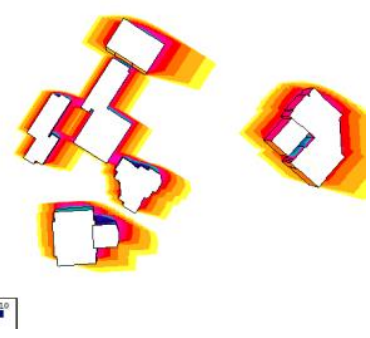

Eylül

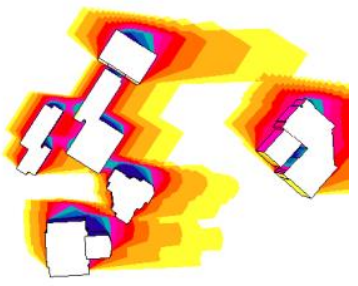

Aralık

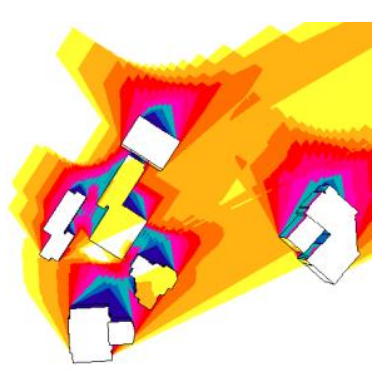

Şekil 10. Amasya Üniversitesi Hâkimiyet Yerleşkesi'nin aylara göre yapılan 3B gölge analizine ait görünümler 


\section{TARTIŞMA VE SONUÇ}

Sürdürülebilirliğin sağlanması yeryüzünde yaşamın devam etmesine olanak sağlayacaktır. Ekoloji bilimi sürdürülebilirliğin türleri ile çevresindeki kaynaklar arasında denge sağlandığına inanmakta olduğu için yeryüzünde var olan mevcut kaynakların doğal yollarla üretimi tüketiminden daha hızlı olmalıdır.

Ekolojik sürdürülebilirlik kavramı, kentlerin hızlı ve kontrolsüz büyümesiyle birlikte ortaya çıkan çevresel sorunların ekolojik alanlar olarak yeniden düzenlenmesi ve planlanmasını sağlamıştır. Bu kavramın temel çıkış noktası, doğanın korunması ve kentlerde yaşam kalitesinin iyileştirilmesidir (Özcan 2007, Vural 2016).

Günümüzde ekolojik sürdürülebilirlik kavramı hava, su, toprak kirliliği gibi çevre sorunlarının ve zamanla çevre üzerinde oluşan tahribatların çözümlenebilmesi ile kent insanına kaliteli yaşam sunulması adına çözüm yolu olarak görülmektedir. Ekolojik sistemde doğal kaynakların hızla tüketilmesinin sonucuna bağlı olarak, sistemlerin çeşitliliğinin ve üretkenliğinin devamının sağlanması yani sürdürülebilirliğini sağlamak önemlidir.

Kentlerde ekolojik sürdürülebilirlik belirli bir alan içerisinde bir çevre sisteminin oluşturulması ve bu alan içerisinde ortaya çıkan sorunların çevresel ilkelere uygun olarak çözülmesine bağlı olarak sağlanmaktadır (Özcan 2007).

Zor (2016) ve Vural (2016)'nın yapmış olduğu çalışmalarda kentlerde ekolojik sürdürülebilirliği sağlamak adına çevre tasarımında doğal kaynakların zarar görme ihtimalini en aza indirgemeli, mevcut topoğrafya formuna uygun ve mevcut yeşil dokuya zarar vermeyen mekânlar tasarlamalı, geri dönüşümlü malzeme kullanılmalı, yenilenebilir enerji kaynakları kullanılmalıdır.

Sürdürülebilir yerleşkelerde birinci hedef doğal kaynakların akılcı kullanımı, ikinci hedef uzun vadede devamlıı̆ı̆ının sağlanması, üçüncü hedef ise konumlandırıldıkları kente örnek teşkil etmeleridir (Büyükkurt 2019). Üniversite yerleşkeleri günümüzde karşılaştı̆ıııı sorunların çözümünde önemli rol oynamaktadır (Günerhan ve Günerhan 2016).

Bir üniversitenin sürdürülebilir olarak adlandırılabilmesi için, o üniversitenin sürdürülebilir faaliyetleri yürütmesi ve bu faaliyetlerin üniversiteye ait tüm yerleşkeler tarafından benimsenmesi gerekmektedir. Bu hususta yerleşke içerisinde yer alan idari ve eğitim binalarının yapısı, yerleşke içerisindeki ulaşım, yerleşkelerin çevre düzeni, atık yönetimi, yerleşkelerde kullanılan bitkiler, enerji kaynaklarının kullanımı gibi üniversiteleri oluşturan bütün unsurların sürdürülebilirliği sağlayıcı şekilde inşa edilmesi önemlidir.

2020 UI GreenMetric Dünya sıralamasında yer alan üniversitelerin yerleşkeleri irdelendiğinde yerleşkelerde ekolojik sürdürülebilirliği sağlamak adına yenilenebilir enerji kaynaklarının sulama, ısınma ve sıcak su temininde kullanıldığı, yağmur suyu toplama kanalları ile yeşil bina ve yeşil çatıların bulunduğu, bina yüzeylerinde ya da çatılarda güneş panellerinin yer aldığı, yağmur suyunun emilimini sağlamak adına yürüyüş ve araç yollarında su geçirimli döşemelerin kullanıldığı, yerleşke içerisinde karbon ayak izini azaltmak adına bisikletle ve yaya olarak ulaşımın sağlandığı, yeşil alanlarda yaz aylarında az suya ihtiyacı olan kış aylarında ise soğuğa dayanıklı bitki türlerinin kullanıldığı görülmektedir (UC Davis 2021, URL2-14 2021).

Çalışmada elde edilen bulgular ışığında; Amasya Üniversitesi Hâkimiyet Yerleşkesi'ndeki eğitim ve idari binaların oluşturduğu gölge sürelerinin Aralık ve Ocak aylarında diğer aylara göre daha fazla olduğu, Haziran ve Temmuz aylarında ise diğer aylara göre gölge sürelerinin daha az olduğu görülmektedir. Bina yakın çevrelerinin açık alanlara göre gölge süreleri fazladır. Buna göre; yerleşkenin 392-400 m. ile 410-420 m. kotları arasında yerleşke sınırlarında yer alan her dem yeşil ağaç ve ağaççıklar ile çalı gruplarının binaların oluşturduğu gölgeden olumsuz etkilenmediği, $400-410 \mathrm{~m}$. kot aralığında bina yakın çevrelerinde yer alan yaprağını döken ağaç ve ağaççık bitki türleri ile çalı gruplarının ise bu durumdan olumsuz etkilendiği belirlenmiştir. Bu bitkiler özellikle yaz aylarında güneşe maruz kalmakta dolayısıyla bitkilerin su isteği ve tüketimi artmaktadır. Bu durum yerleşkenin su tüketimini arttırarak ihtiyacından fazla su tüketiminde bulunmasına neden olmakta ve bitkilerin gelecekte sağlıklı gelişimleri için bir tehdit unsuru oluşturabilecektir. Amasya Üniversitesi Hâkimiyet Yerleşkesi'nde ekolojik sürdürülebilirliği sağlamak adına aşağıda belirtilen öneri uygulamalar yapılabilir:

- Su tüketimini minimuma indirgemek için yağmur suları biriktirilerek ve atık sular arıtılarak bitkilerin sulanmasında kullanılmalıdır.

- Yerleşkede yağmur suyu emilimini sağlamak adına otopark alanlarında ve yürüyüş yollarında mevcutta kullanılan beton yüzey su geçirimli döşemelerle değiştirilmelidir. 
- 3B gölge analizi doğrultusunda idari bir bina olan Rektörlük binasında yeşil çatı uygulaması yapılmalıdır.

- Yerleşke açık yeşil alanlarında ve bina yakın çevrelerinde yer alan bitki türlerinin Amasya kent iklimine uygun kış aylarında soğuğa dayanıklı yaz aylarında da hem güneşe dayanaklı hem de su ihtiyacı az olan bitki türleri ile çok yıllık yer örtücü bitkiler tercih edilmelidir.

- Yerleşkede yer alan mevcut 16 adet yaprağını döken ağaç ve ağaç̧̧ı bitki türüne alternatif olarak Amasya kent iklimine uygun Prunus serrulata (Süs Kirazı), Acer palmatum (Japon Akçaağacı), Betula pendula 'Youngii' (Ters Aşılı Huş), Lagerstroemia indica (Oya Ağacı), Liriodendron tulipifera (Lale Ağacı), Fraxinus excelsior (Dişbudak), Acer platanoides (Çınar Yapraklı Akçaağaç), Acer saccharum (Şeker Akçaağacı), Tilia cordata (Küçük Yapraklı Ihlamur), Casuarina equisetifolia (Demir Ağacı), Salix caprea (Keçi Söğüdü), Betula pendula (Akhuş), Carpinus betulus (Gürgen), Fagus sylvatica (Kayın), Alnus glutinosa (Kızıl Ağaç), Quercus rubra (Amerikan Meşesi), Coryllus colurna (Türk Findığı), Laburnum anagyroides (Sarı Salkım), Gleditsia triancanthos (Glediçya) Cotinus coggyria (Bulut Ağacı) kullanılarak yerleşkedeki yaprağını döken ağaç ve ağaççık bitki türü sayısı arttırılmalıdır.

- Yerleşkede yer alan 7 adet her dem yeşil ağaç ve ağaççık bitki türüne alternatif olarak Pinus brutia (Kızıl Çam) Pinus griffithii (Ağlayan Çam), Calocedrus decurrens (Kalifornia Su Sediri) kullanılarak yerleşkedeki her dem yeşil ağaç ve ağaç̧̧ı bitki türü sayısı arttırıımalıdır.

- Yerleşkede yer alan mevcut 5 adet çalı grubuna alternatif olarak Photinia serrulata (Alev Çalısı), Oenothera lindheimeri (Gaura), Viburnum tinus (Adiponpon Kartopu), Buddleja davidii (Kelebek Çalısı), Erica manipuliflora (Erica), Abelia grandiflora (Abelia), Lonicera caprifolium (Hanımeli), Hibiscus syriacus (Ağaç Hatmi), Mahonia aquifolium (Mahonya), Ligustrum japonicum var. (Alacalı Kurtbağrı), Pyracantha coccinea 'Nana' (Bodur Ateş Dikeni), Ilex aquifolium (Çoban Püskülü), Berberis thunbergii (Kadın Tuzluluğu), Juniperus squamata 'Blue Carpet' (Mavi Kilim Ardıcı), Juniperus virginiana (Kurşunkalem Ardıcı), Pinus mugo (Bodur Dağ Çamı), Taxus baccata (Adi Porsuk), Juniperus sabina (Sabina Ardıcı) kullanılarak yerleşkedeki çiçekli ve her dem yeşil çalı grubu sayısı arttırılmalıdır.

- Yerleşke açık yeşil alanlarında ve bina yakın çevrelerinde Drosanthemum floribundum (Acem Halısı), Sedum sp. (Dam Koruğu), Limonium sinuatum (Kunduz Otu), Lobularia maritima (Alisyum), Jasminum fruticans
(Sarı Çiçekli Yasemin), Pelargonium zonale (Top Sardunya), Petunia hybrida (Petunya), Osteospermum ecklonis (Bodrum Papatyası), Viola odorata (Menekşe), sarmaşık amaçı Wisteria sinensis (Mor Salkım), Campsis radicans (Acem Borusu) gibi çok yıllık yer örtücü bitkiler kullanılmalıdır.

- Önerilen çok yıllık yer örtücü bitki türlerinden kış mevsimi için Viola odorata (Menekşe), yaz mevsimi için de Petunia hybrida (Petunya)'nın kullanımı Amasya kent iklimine daha uygundur.

Kentlerde ya da küçük ölçekte kent modeli olarak değerlendirilen yerleşkelerde kullanılacak bitki türlerinin seçiminde binaların gölge analizlerinin yapılması ve bu doğrultuda bitki türlerinin seçilip dikilmesi ekolojik sürdürülebilirliği sağlamak adına arzu edilen bir yaklaşımdır. Hem kentlerde hem de yerleşkelerde yer alan açık yeşil alanlar birçok hayvan için de habitat yani yaşam alanı olma özelliği göstermektedir. Yerleşkelerde yeşil alanların birbirine bağlanması kampüslerin daha okunabilir, daha öğretici ve ekolojik olarak sürdürülebilir olmalarını sağlayacaktır. Bu çalışmanın diğer üniversite yerleşkeleri için de örnek olacağı düşünülmektedir.

\section{BILGILENDIRME}

Bu çalışma, Amasya Üniversitesi Fen Bilimleri Enstitüsü Teknoloji ve İnovasyon Yönetimi Anabilim Dalı yüksek lisans öğrencisi Mustafa Taha KESKiNER'in 'Ekolojik Sürdürülebilirlik Kavramının 3B Gölge Analizi Tekniği ile Amasya Üniversitesi Hâkimiyet Yerleşkesi Örneğinde İrdelenmesi' başılıkı yüksek lisans tez çalışmasının bir parçasıdır.

\section{KAYNAKLAR}

Büyükkurt U (2019) Sürdürülebilir Kampüslerde Su Tasarrufuna Yönelik Çalışmalar. Karadeniz Teknik Üniversitesi Fen Bilimleri Enstitüsü Yüksek Lisans Tezi, Trabzon, $97 \mathrm{~s}$

Colantonio A, Dixon T (2011) Urban regeneration and social sustainability: Best practice from European cities. John Wiley \& Sons, New York

Cole MA (1999) Limits to growth, sustainable development and environmental Kuznets curves: an examination of the environmental impact of economic development. Sustainable Development 7(2):87-97

Costanza R (1999) The ecological, economic, and social importance of the oceans. Ecological Economics 31:199-213

Goodland R (2002) Sustainability: Human, Social, Economic and Environmental. In: Harold AM, Josep GC (ed) Encyclopedia of Global Environmental Change, John Wiley\&Sons, New York, pp 220-225 
Güllü G, Köksal MA, Şengül H (2012) Dünyada ve Türkiye'de Sürdürülebilir Kampüs Uygulamaları. Kalkınmada Anahtar Verimlilik Dergisi 284:24-30

Günerhan SA, Günerhan H (2016) Türkiye İçin Sürdürülebilir Üniversite Modeli. Mühendis ve Makina 57(682):54-62

Kurt Konakoğlu SS, Usta Z (2019) Ekolojik Sürdürülebilirlik Kavramının 3B Gölge Analizi ile KTÜ Kanuni Kampüsü Örneğinde İrdelenmesi. In: Bildiriler Kitabı TMMOB 6. Coğrafi Bilgi Sistemleri Kongresi, Ankara, Türkiye, pp 976-985

McDonough W (1992) The Hannover Principles: Design for Sustainability. William McDonough Architects, New York

Muscoe M (1995) A Sustainable Community Profile. Places 9(3):30-37

Orr M (2010) Intertextuality. The encyclopedia of literary and cultural theory. John Wiley\&Sons, England

Özcan A (2007) Ekolojik Temele Dayalı Sürdürülebilir Kentsel Gelişme: Malatya Kent Örneği Üzerinden Bir Değerlendirme. In: Bildiriler Kitabı 38. Uluslararası Asya ve Kuzey Afrika Çalışmaları Kongresi, Ankara, Türkiye, pp 689-710

Özdal Oktay S, Özyılmaz Küçükyağcı P (2015) Üniversite Kampüslerinde Sürdürülebilir Tasarım Sürecinin İrdelenmesi. In: Proceedings of 2nd International Sustainable Buildings Symposium, Ankara, Türkiye, pp 564-571

UC Davis (2021) URL: https://www.ucdavis.edu/about. Erişim Tarihi 17 Ocak 2021

UNEP (2013) Greening Universities Toolkit: Transforming Universities into Green Campuses. URL: https://www.unenvironment.org/resources/toolkits-manualsand-guides/greening-universities-toolkit-v20. Erişim Tarihi 24 Ocak 2021

URL-1

https://tr.wikipedia.org/wiki/Sosyal_s\%C3\%BCrd\%C3\%BCr\%C3\% BClebilirlik\#: :text=Sosyal. Erişim Tarihi 15 Aralık 2020

URL-2 (2021) https://www.adelaide.edu.au/tours/. Erişim Tarihi 17 Ocak 2021

URL-3 (2021) https://en.wikipedia.org/wiki/University_of_Adelaide. Erişim Tarihi 17 Ocak 2021
URL-4 (2021) https://tr.maps-adelaide.com/adelaide-kamp\%C3\%BCsharitas\%C4\%B1. Erişim Tarihi 17 Ocak 2021

URL-5 (2021) https://www.nottingham.ac.uk/. Erişim Tarihi 17 Ocak 2021

URL-6 (2021)

https://tr.wikipedia.org/wiki/Nottingham_\%C3\%9Cniversitesi. Erişim Tarihi 17 Ocak 2021

URL-7 (2021) http://greenmetric.ui.ac.id/overall-rankings-2020/. Erişim Tarihi 18 Ocak 2021

URL-8 (2021) https://www.itu.edu.tr/hakkimizda. Erişim Tarihi 18 Ocak 2021

URL-9 (2021) https://yesilkampus.itu.edu.tr/. Erişim Tarihi 18 Ocak 2021

URL-10 (2021) https://www.metu.edu.tr/tr/tarihce. Erişim Tarihi 19 Ocak 2021

URL-11 (2021) https://www.metu.edu.tr/tr/konum-ve-yerleske. Erişim Tarihi 19 Ocak 2021

URL-12 (2021) https://kampus.metu.edu.tr/en/science/sustainablegreen-campus-management-metu-campus-application. Erişim Tarihi 19 Ocak 2021

URL-13 (2021) https://w3.beun.edu.tr/hakkimizda/tarihce.html. Erişim Tarihi 20 Ocak 2021

URL-14 (2021) https://greenmetrics.beun.edu.tr/kampuslerimiz/yesilkampuslerimiz.html. Erişim Tarihi 20 Ocak 2021

Vivien FD (2008) Sustainable Development: An Overview of Economic Proposals. SAPIENS 1(2):1-8

Vural NH (2016) Ekolojik Sürdürülebilirlik Çerçevesinde Cendere Vadisi Dönüşümünün Mimarlık Bağlamında Değerlendirilmesi Silahtarağa-Kâğıthane Merkez Mahallesi Aksı Örneği. Fatih Sultan Mehmet Vakıf Üniversitesi Mühendislik ve Fen Bilimleri Enstitüsü Yüksek Lisans Tezi, İstanbul, $107 \mathrm{~s}$

Zor A (2012) "Geleneksel Konut Yapılarının” Korunmasının Ekolojik Dengeye Sağladığı Katkılar Üzerine Bir İnceleme. Yıldız Teknik Üniversitesi Fen Bilimleri Enstitüsü Yüksek Lisans Tezi, İstanbul, $168 \mathrm{~s}$ 